\title{
Invasive vascular plant species of oxbow lakes in south-western Poland
}

\author{
Krzysztof Spałek
}

Laboratory of Geobotany and Plant Conservation, Department of Biosystematics, University of Opole, Oleska 22, 45-052 Opole, Poland, e-mail: kspalek@uni.opole.pl

\begin{abstract}
Natural water reservoirs are very valuable floristic sites in south-western Poland. Among them, the most important for the preservation of biodiversity of flora are oxbow lakes. The long-term process of human pressure on habitats of this type caused disturbances of their biological balance. Changes in the water regime, industrial development and chemisation of agriculture, especially in the period of the last two hundred years, led to systematic disappearances of localities of many plant species connected with rare habitats and also to the appearance of numerous invasive plant species. They are: Azolla filiculoides, Echinocystis lobata, Erechtites hieraciifolia, Impatiens glandulifera, I. parviflora, Reynoutria japonica, Solidago canadensis, S. gigantea and S. graminifolia. Field works were conducted in years 2005-2012.
\end{abstract}

Key words: invasive plant species, phytocoenoses, oxbow lakes, distribution, south-western Poland

\section{Introduction}

A breakthrough in river valley transformations took place in the $18^{\text {th }}$ century and it was connected with the industrial revolution. Not only did it accelerate regulatory works on majority of Europe's bigger rivers, but it also led to a mass transformation of natural watercourses into canals. Riverbeds were being shortened, deepened and regulated on a large scale. Recreation of the potential of once transformed river valleys is currently very difficult and, in most cases, even impossible. However, in order to accomplish this goal, it is necessary to know the conditions prevalent in the whole valley and limit degradation factors (Olaczek 2000; Horska-Schwarz 2006). Many plant species are strictly dependant on river valleys; they form a group of so-called ,river corridor species". For the lowland part of Central Europe, 129 taxons have been identified, including numerous invasive species (Burkart 2001). Permanently established species of alien origin, including invasive species are common also in the south-west of Poland (e.g. AniolKwiatkowska et al. 1992; Dajdok et al. 1998, 2003; Dajdok \& Kącki 2003; Spałek 2003; Tokarska-Guzik $\&$ Dajdok 2004). In the course of the present research, plant species of this type were found; however, rarely in the oxbow lakes, mainly of the Oder.

\section{Material and methods}

The field work was conducted during the growth seasons in years 2005-2012. Lemno-Azoletum filiculoides community was studied with the methods of the ZurichMontpellier School of Phytosociology (Braun-Blanquet 1964). The phytosociological nomenclature and the syntaxonomical appendix are based on Oberdorfer (1994) and Matuszkiewicz (2005). The species names of vascular plants are given according to Mirek et al. (2002). The assessment of the physical and chemical properties of the habitat was determined in the field work, when the $\mathrm{pH}$ of water was measured in the spring at depths of 0-20 cm and 20-40 cm with the assistance of Elmetron multipurpose measuring device.

\section{Results and discussion}

Azolla filiculoides Lam. (Lamarck in Lamarck et al. 1783)

First information from the area within the borders of the present-day Poland came from Lower Silesia. Azolla filiculoides was identified in the palace pond in Wawrzyszów near Strzelin, where it overwintered several times (Schube 1928). After 1945, this species was reported in Bielsk Podlaski (Wołkowycki 1999), 
Table 1. Lemno-Azolletum filiculoides Br.-B1. 1952 in oxbow lakes near Kobierzyce

\begin{tabular}{|c|c|c|c|c|c|c|c|c|c|c|c|}
\hline Relevé number & 1 & 2 & 3 & 4 & 5 & 6 & 7 & 8 & 9 & 10 & $\mathrm{C}$ \\
\hline Date & $\begin{array}{c}11.08 . \\
2011\end{array}$ & $\begin{array}{c}11.08 . \\
2011\end{array}$ & $\begin{array}{c}11.08 \\
2011\end{array}$ & $\begin{array}{c}11.08 . \\
2011\end{array}$ & $\begin{array}{c}11.08 . \\
2011\end{array}$ & $\begin{array}{c}11.08 . \\
2011\end{array}$ & $\begin{array}{c}02.09 \\
2011\end{array}$ & $\begin{array}{c}02.09 \\
2011\end{array}$ & $\begin{array}{c}17.07 . \\
2011\end{array}$ & $\begin{array}{c}17.07 . \\
2011\end{array}$ & \\
\hline Cover of herb layer [\%] & 80 & 65 & 70 & 60 & 50 & 80 & 60 & 70 & 50 & 45 & \\
\hline Area of relevé $\left[\mathrm{m}^{2}\right]$ & 50 & 50 & 50 & 50 & 50 & 50 & 100 & 50 & 50 & 50 & \\
\hline Number of species in relevé & 4 & 3 & 4 & 4 & 3 & 3 & 4 & 4 & 3 & 4 & \\
\hline \multicolumn{12}{|c|}{ Ch. Lemno-Azolletum filiculoides } \\
\hline Azolla filiculoides & 3 & 3 & 3 & 3 & 3 & 3 & 3 & 3 & 3 & 3 & V \\
\hline \multicolumn{12}{|c|}{ Ch. Lemnetalia minoris, Lemnetea minoris } \\
\hline Lemna minor & 3 & 3 & 3 & 3 & 3 & 3 & 2 & 3 & + & 1 & $\mathrm{~V}$ \\
\hline Spirodela polyrhiza & 1 & 1 & 1 & 2 & 1 & 2 & 1 & 1 & 2 & 2 & $\mathrm{~V}$ \\
\hline Salvinia natans & . & . & . & . & . & . & . & . & . & + & I \\
\hline \multicolumn{12}{|l|}{ Ch. Potametea } \\
\hline Nuphar lutea & + & . & + & + & . & . & + & 1 & . & . & III \\
\hline
\end{tabular}

Explanations: Ch. - characteristic species, C - constancy of Wolffia arrhiza

Siedlisko near Nowa Sól (Rosadziński 2008) and sites located in the south-west of Poland: Wrocław, Wilkszyn, Koźlice (Szczęśniak 2009; Szczęśniak et al. 2009). In the course of the present research, Azolla filiculoides was recognised in significant numbers in Kościerzyce near Brzeg in two oxbow lakes of the Oder (N 50 $87.721^{\prime}$, E 17053.052'and N 50 $86.626^{\prime}$, E 17'54.749') in Lemno-Azolletum filiculoides phytocoenoses. This community was growing in 10 to 160 $\mathrm{cm}$ deep waters with $\mathrm{pH} 7.2-7.8$ on silty as well as silty-sandy subsoil. Its lobes were dominated by Azolla filiculoides and Lemna minor as well as Spirodela polyrhiza (Table 1). From 3 to 4 (with 4 on average) species were identified. In its phytocoenoses, a total number of 5 plant species were reported. The floristic composition of Lemno-Azolletum filiculoides patches in Kobierzyce was usually very similar to phytocoenoses of this community from other areas of Poland (Szczęśniak et al. 2009) and neighbouring countries (Ot'ahel'ová 1995; Passarge 1996; Šumberová 2011).

\section{Echinocystis lobata (F. Michx.) Torr. \& A. Gray}

In the course of the current research, several dozens of this species were reported in the Oder oxbow lake in Ścinawa near Oława in Lower Silesia (N 50 ${ }^{\circ} 92.889^{\prime}$, E 17 $\left.{ }^{\circ} 34.154^{\prime}\right)$ within Phragmitetum australis and in the Oder oxbow in Boguszyce near Opole (N 50 60.067', E 17'95.452') within Glycerietum maximae and Typhetum latifoliae. So far, this species was not reported in the south-west of Poland in this type of habitat.

Erechtites hieraciifolia (L.) Raf. ex DC.

A few specimens of this species were found in the Oder oxbow lake in Ścinawa near Oława (N 50²92.889', E 17³4.154') in Phragmitetum australis. It is very rarely reported in this type of habitat (Górski et al. 2003).

\section{Impatiens glandulifera Royle}

Several dozens of the species were reported in the oxbow lake of the Nysa Kłodzka River near Bielice in Opole Silesia (N 5055.799', E 1748.184') within Phragmitetum australis. So far, this species was not reported in the south-west of Poland in this type of habitat.

\section{Impatiens parviflora DC.}

Several dozens of the species were reported in the oxbow lake of the Oder in Boguszyce (N 50 $60.067^{\prime}$, E 17 $\left.{ }^{\circ} 95.452^{\prime}\right)$ within Phragmitetum australis and Typhetum latifoliae. So far, this species was not reported in oxbow lakes of the south-west of Poland.

\section{Reynoutria japonica Houtt.}

Several specimens of this species were reported in the oxbow lake of the Nysa Kłodzka River near Bielice (N 50 55.799', E 17²8.184') within Phragmitetum australis. So far, this species was not reported in this type of habitats.

\section{Solidago canadensis L.}

Several dozen specimens of this species were reported in the oxbow lake of the Oder in Boguszyce ( $\mathrm{N}$ 50 60.067', E 17 ${ }^{\circ} 95.452$ ') within Glycerietum maximae, Phragmitetum australis and Typhetum latifoliae. So far, this species was not reported in oxbow lakes of the south-west Poland.

\section{Solidago gigantea Aiton}

Several dozen specimens of this species were reported in the oxbow lake of the Oder near Malczyce $(\mathrm{N}$ 
51 $\left.1^{\circ} 2.757^{\prime}, \mathrm{E} 16^{\circ} 48.413^{\prime}\right)$ and Głogów (N 51 ${ }^{\circ} 66.813^{\prime}, \mathrm{E}$ $\left.16^{\circ} 09.660^{\prime}\right)$ and in the oxbow lake of the Barycz River near Bełcz Mały in Lower Silesia (N 51 ${ }^{\circ} 57.363^{\prime}$, E $16^{\circ} 65.318^{\prime}$ ) within Phragmitetum australis. So far, this species was not reported in oxbow lakes of the southwest of Poland.

\section{Solidago graminifolia (L.) Elliott}

Several hundred specimens of this species were reported in the oxbow lake of the Oder in Boguszyce $(\mathrm{N}$ 50 60.067', E 17'95.452') within Glycerietum maximae, Phragmitetum australis and Typhetum latifoliae. So far, this species was not reported in plant oxbow lakes in Poland.

\section{Conclusion}

The current research proved the occurrence of 9 invasive species in the oxbow lakes of south-west
Poland. Most of them appeared, usually not numerously, in rush communities of Phragmitetea class, most often in Phragmitetum australis phytocoenoses. Only Azolla filiculoides created lobes of its community Lemno-Azoletum filiculoides. The invasive species were identified only in the oxbow lakes in the vicinity of illegal waste dumps or, less commonly, in oxbow lakes adjacent to agricultural land. As far as remedial actions are concerned, using chemicals in aquatic communities is unacceptable. As the populations of invasive species are usually small in this type of habitat, the only and the best way to eliminate them is to remove them manually, including Azolla filiculoides. Due to numerous plant migrations in the river valleys, it is supposed that invasive species will appear more often in oxbow lakes. The potential and biggest danger to the flora and community of plant oxbow lakes of south-west Poland may be Azolla filiculoides.

\section{References}

Aniol-Kwiatkowska J., Berdowski W. \& Wóscik G. 1992. Synantropizacja obszarów chronionych w Masywie Ślęży. Acta Univ. Wratisl. 1358 Pr. Bot. 48: 3-44.

Braun-Blanquet J. 1964. Pflanzensoziologie, Grundz ge der Vegetationskunde. 865 pp. Dritte Auflage. Springer Verlag, Wien-New York.

BuRKART M. 2001. River corridor plants (Stromtalplanzen) in Central European lowland: a review of a poorly understood plant distribution pattern. Global Ecol. Biogeogr. 10: 449-468.

Dajdok Z., Aniol-Kwiatkowska J. \& Kącki Z. 1998. Impatiens glandulifera Royle in the floodplain vegetation of the Odra river (West Poland). In: U. STARfinger, K. Edwards, I. Kowarik \& M. Williamson (eds.). Plant invasions: ecological mechanisms and human respondes, pp. 161-168. Backhuys Publishers, Leiden, the Netherlands.

Dajdok Z., AnioŁ-Kwiatkowska J. \& Kącki Z. 2003. Distribution of Impatiens glandulifera along the Odra river. In: A. ZAJAcC, M. ZAJĄC \& B. ZEMANEK (eds.). Phytogeographical problems of synanthropic plants, pp. 125-130. Institute of Botany, Jagiellonian University, Cracow.

DAJDOK Z. \& KĄCKI Z. 2003. Kenophytes of the Odra riversides. In: A. ZaJĄC, M. ZajĄC \& B. ZemaneK (eds.)., Phytogeographical problems of synanthropic plants, pp. 131-136. Institute of Botany, Jagiellonian University, Cracow.

Górski P., Czarna A. \& Tokarska-Guzik B. 2003. Distribution of Erechtites hieracifolia (L.) Raf. ex DC. (Asteraceae) in Poland. In: A. ZAJĄC, M. ZAJĄC \& B. Zemanek (eds.), Phytogeographical problems of synanthropic plants, pp. 147-1153. Institute of Botany Jagiellonian University, Cracow.
HorSKA-Schwarz S. 2006. Ewolucja starorzeczy jako przejaw starzenia się geokompleksów dolinnych w oparciu o powierzchnie testowe doliny Odry Oława - Wrocław. In: A. Richling, B. Stojek, M. Strzyż, I. Szumacher \& A. Świercz (eds.), Regionalne studia ekologicznokrajobrazowe. Problemy ekologii krajobrazu 16(1): 161-169.

Matuszkiewicz W. 2005. Przewodnik do oznaczania zbiorowisk roślinnych Polski. In: J. B. FALIŃSKI (ed.). Vademecum Geobotanicum 3, 537 pp. Wyd. Nauk. PWN, Warszawa.

Mirek Z., Piękoś-Mirkowa H., Zając A. \& Zając M. 2002. Flowering plants and pteridophytes of Poland. A checklist. In: Z. MireK (ed.). Biodiversity of Poland, 1, 442 pp. W. Szafer Institute of Botany, Polish Academy of Sciences, Kraków.

OBERDORfER E. 1994. Pflanzensoziologische Exkursionsflora. 7 Aufl. 1050 pp. Verl. Eugen Ulmer, Stuttgart.

OLACZEK R. 2000. Antropogeniczne czynniki przekształcenia dolin rzecznych. Rzeki 9: 119-142.

OT’AHEL'OvÁ H.1995. Lemnetea. In: M. Valachovič (ed.), Rastlinné spoločenstwa Slovenska. 1. Pionierska vegetácia, pp. 131-150. Veda, Bratislava.

Passarge H. 1996. Pflanzengesellschaften Nordostdeutschlands. I. Hydro- und Therophytosa. 283 pp. J. Cramer, Berlin-Stuttgart.

RosAdZIŃsKi S. 2008. Azolla w dolinie środkowej Odry. Bociek 94(2): 9-10.

SchuBE T. 1928. Ergebnisse der Durchforschung der schlesischen Gefässpflanzenwelt im Jahre 1927. JahresBericht. Der Schles. Ges. Vaterl. Cultur. 80: 33-59.

SpaŁeK K. 2003. Rare and endangered synanthropic plants of the Opole Plain (SW Poland). In: A. ZAJĄC, M. ZAJĄC \& B. Zemanek (eds.), Phytogeographical problems of 
synanthropic plants, pp. 325-330. Institute of Botany, Jagiellonian University, Cracow.

Šumberová K. 2011. Vegetation of free floating aquatic plants. In: M. СнYTRÝ (ed.), Vegetation of the Czech Republic. 3. Aquatic and Wetland Vegetation, pp. 4399. Academia, Praha.

SzCZĘŚNIAK E. 2009. Azolla paprotkowata (Azolla drobna) - Azolla filiculoides Lam. (Lamarck in Lamarck et al. 1783). In: Z. Dajdok \& P. Pawlaczyk (eds.), Inwazyjne gatunki roślin ekosystemów mokradłowych Polski, pp. 32-35. Wyd. Klubu Przyrodników, Świebodzin.
Szczęśniak E., Błachuta J., Krukowski M. \& PicińskaFaŁtynowicz J. 2009. Distribution of Azolla filiculoides Lam. (Azollaceae) in Poland. Acta Soc. Bot. Pol. 78(3): 241-246.

Tokarska-GuziK B. \& Dajdok Z. 2004. Rośliny obcego pochodzenia - udział i rola w szacie roślinnej Opolszczyzny. In: A. NowaK \& K. Spatek (eds.), Ochrona szaty roślinnej Śląska Opolskiego, pp. 277-303. Uniwersytet Opolski, Opole.

WoŁkowycki D. 1999. Azolla filiculoides (Pteridophyta, Azollaceae) w Polsce. Fragm. Flor. Geobot. Polonica 6: $165-170$ 